\title{
Spermatological Parameters of Extended Rabbit Semen in 5\% Indigenous Poultry Egg Yolk Plasma-Biofortified Extender.
}

\author{
Popoola, M. A. ${ }^{1}$, Alemede, C. I. ${ }^{2}$, Aremu, A. ${ }^{2}$, Ola, S.I. ${ }^{3}$, Popoola, Y. R. ${ }^{4}$ and \\ Yusuf, O. H. ${ }^{1}$ \\ ${ }^{1}$ National Biotechnology Development Agency, Abuja, Nigeria. ${ }^{2}$ Federal University of Technology, Minna, \\ Nigeria. ${ }^{3}$ Obafemi Awolowo University, Ile Ife, Nigeria. ${ }^{4}$ National Identity Management Commission, \\ Abuja, Nigeria.
}

\begin{abstract}
The in vitro evaluation of spermatological parameters is of great importance in the validation of semen samples to be used in artificial insemination. This study was aimed at evaluating the effect of $5 \%$ egg yolk plasma from 5 Nigerian domesticated avian species as a component of semen extender in the preservation of rabbit semen to be used for field fertility trials. The evaluated parameters (\%) pre and post chilling storage were mass motility, forward progressive motility (FPM), liveability, acrosome integrity and total abnormalities at $37{ }^{\circ} \mathrm{C}, 0$ hours, $5{ }^{\circ} \mathrm{C}, 24$ hours and $5{ }^{\circ} \mathrm{C}, 48$ hours. The $5 \%$ egg yolk plasma (EYP) was locally sourced from Chicken, Guinea fowl, Quail, Turkey and Muscovy bio assayed egg yolk samples. Semen samples used were aliquoted from the heterospermic pool of 20 bucks maintained under the same husbandry management regime. The result showed that at $37{ }^{\circ} \mathrm{C}$ post extension but pre-chilling storage, mass motility (\%) in guinea fowl egg yolk plasma (GEYP) extended rabbit semen was significantly different $(P<0.05)$ from that of the other samples compared except for Muscovy. The best acrosome integrity was recorded in Turkey (EYP) extended rabbit semen $76.00 \%$ while the best abnormality of $9.67 \%$ was recorded with quail (EYP). After chilling for 24 hours at $5{ }^{\circ} \mathrm{C}$, the best combination of spermatological parameters was found in quail egg yolk plasma (QEYP) containing extender

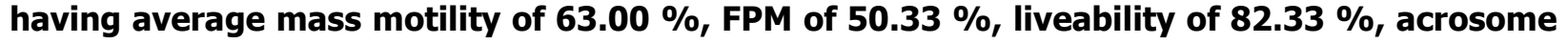
integrity of $66.00 \%$ and total abnormality of $6.67 \%$ being the least. At 48 hours, QEYP extended semen gave the best result with the highest values of $74.67 \%, 62.33 \%, 81.67 \%$ and $\mathbf{7 8 . 0 0} \%$ for mass motility, FPM, liveability and acrosome integrity respectively. Quail (EYP) could be used as an alternative to chicken (EYP) in the production of semen extender for rabbit semen chilling storage.
\end{abstract}

(Received: 13:03:2017: Accepted: 14:04:2017)

KEY WORDS: rabbit semen, egg yolk plasma, chilling storage, avian species.

Correspondence: honmusty@gmail.com

\section{Introduction}

Domestic rabbits (Oryctolaguscuniculus) are ubiquitous, providing protein, fibre, research models and companionship. Rabbits have high reproductive potentials and fast growth rate (Hassan et. al., 2012). Rabbit farming in Nigeria is faced with myriad of problems, which have resulted in gross shortage of meat and therefore unable to meet up the demand of an increasing population of Nigerians (Nworgu, 2007). These problems range from nutritional challenges to availability of assisted reproductive techniques, most especially artificial insemination (AI) technique. Despite the use of AI in the large rabbit farms of several European countries, rabbit AI has certainly not become a common practice in the rabbit meat producing areas of the world (Roca et. al., 2000). 
A limiting factor for a more extensive commercial application is related to the semen preservation. The current practice of using freshly diluted semen is mostly limited to AI of does on the farm where the buck is located and within a few hours of semen collection (Brun et. al., 2002). Egg yolk is normally used as a cryoprotective agent in semen freezing extenders, but its use has sanitary and practical disadvantages. Plasma contains mainly Low Density Lipoproteins (LDL), which are widely presumed to be the cryoprotective agent in egg yolk. Plasma can be produced on an industrial scale, sterilized by gamma-irradiation and incorporated in a ready-to-use extender compared to whole egg yolk (Pillet et. al., 2011). Moreover, the protection afforded by egg yolk has not yet been completely elucidated. Thus, a comparison effect of egg yolk and egg yolk plasma of different avian species (domestic chicken, turkey, Muscovy, Japanese quail and guinea fowl) in the extender on the efficiency of chilling preservation of rabbit sperm is desirable.

\section{Materials and Methods}

The rabbit buck and their managements

Twenty (20) mixed breed matured rabbit bucks were used. The animals were fed with both concentrates and forages. The rabbits were kept under natural lighting condition of 1112 hours light period per day throughout the experimental period. Oxytetracycline (20\%) was administered intramuscularly to all the experimental animals as broad spectrum antibiotics for prophylaxis treatment. The animals were kept in individual rabbit hutches and maintained under a uniform and constant nutritional regimen at the Teaching and Research Farm, Obafemi Awolowo University, Ile Ife, Nigeria. Cool clean water was supplied ad libitum on a daily basis.

\section{Preparation of rabbit semen extenders}

Egg-yolk plasma (EYP) from five different poultry species namely chicken, quail, turkey, guinea fowl and Muscovy were used. Five extenders were prepared using the egg yolk plasma from five (5) avian species at $5 \%$ graded inclusion levels (5\% EYP from 5 avian species). Chicken egg yolk extender serves as the control treatment. The other constituents of the extender were the same (El-Sherbieny et. al., 2012). All extenders for the preservation of rabbit semen were stored at $5^{\circ} \mathrm{C}$. The detailed composition of the extenders is as shown in Table 1

\section{Table 1: Composition of Rabbit Semen Extenders with Egg Yolk Plasma (EYP)}

\begin{tabular}{ll} 
Ingredients & Composition \\
Egg yolk plasma (\%) & 5.00 \\
Trishydroxymethylaminomethane $(\mathrm{g})$ & 0.30 \\
Citric acid(g) & 0.17 \\
Fructose $(\mathrm{g})$ & 0.13 \\
Streptomycin(g) & 0.05 \\
Normal saline (Add to make up $\mathrm{ml})$ & 10.00 \\
\hline
\end{tabular}

\section{Semen collection and evaluation}

Semen was collected from the bucks with the use of artificial vagina warmed with water at $40{ }^{\circ} \mathrm{C}$ to equilibrate the temperature of the artificial vagina to mimic the average temperature of doe vagina. The experienced bucks were introduced to the does to ensure natural stimulation for ejaculation. The penis of the bucks was located to ensure penetration into the artificial vagina for onward ejaculation. Semen was collected two times a week and only ejaculates with minimum of $0.5 \mathrm{ml}$ volume were used in this research work. Gels in ejaculates were removed using micropipette and collected semen transferred to the laboratory for assessment, processing and storage.

The rabbit semen collected from the field was transferred to the laboratory using a flask containing warm water to maintain the semen temperature at $40{ }^{\circ} \mathrm{C}$. The parameters assessed and recorded in percentage (\%) were the sperm mass motility (MM), forward progressive motility (FPM), live ability (live: dead), acrosome integrity and total abnormalities. 
The volume of semen used for the assessment of each parameter evaluated was measured with Eppendorf pipette. The concentration of spermatozoa greater than or equal to 50 million cells $/ \mathrm{ml}$ and the proportion of motile cells greater than or equal to $70 \%$ were used. The concentration was estimated using a haemocytometer.

To evaluate the Mass motility and FPM percentages, samples $(10 \mu \mathrm{L})$ of the fresh spermatozoa at $37^{\circ} \mathrm{C}$ was placed under a cover slip (22 mm x $22 \mathrm{~mm}$ ) in the centre of a prewarmed $\left(37^{\circ} \mathrm{C}\right)$ slide and then transferred to a heated microscope stage set at $37^{\circ} \mathrm{C}$ and assessed by phase contrast microscopy (x200 magnifications). The proportion of motile sperm cells and spermatozoa with progressive motility were estimated.

Liveability and proportion of morphologically abnormal spermatozoa (total abnormality, abnormal head, tail and mid piece) were assessed by staining the aliquots of the sperm suspension with eosin- nigrosin and Giemsa (Cassinello et. al., 1998). Acrosome integrity of the semen samples were examined by phase-contrast microscopy using $x 100$ oil immersion objective after staining with Congo red and the slides were fixed with ethanol.

Semen processing and chilling storage

The rabbit semen exhibiting the good quality was processed for cold storage. The processing of spermatozoa involved dilution of fresh semen and different extenders at a ratio of $1: 5$. The extended semen was transferred into the refrigerator for cold storage. Chilling of semen was carried out by keeping the extended semen at $5^{\circ} \mathrm{C}$ for 24 and 48 hours. The evaluation of all the spermatological parameters as detailed above was carried out and values recorded in percentages at $\left(37^{\circ} \mathrm{C}, 0\right.$ hour $),\left(5^{\circ} \mathrm{C}\right.$, 24 hours) and $\left(5^{\circ} \mathrm{C}, 48\right.$ hours $)$.

\section{Experimental design}

The experimental design used in the studies was completely randomized design (CRD). The first phase is for the evaluation of extended rabbit semen at $\left(37^{\circ} \mathrm{C}, 0\right.$ hour) with chicken egg yolk plasma being the control (conventional egg yolk based extenders were made from hen egg yolk). This procedure was carried out for extended rabbit semen stored at $5^{\circ} \mathrm{C}$ or 24 and 48 hours representing the second and third phases of the experiment respectively. Each treatment has 3 replicates in all the phases and all the 5 parameters evaluated were the same in all cases.

\section{Statistical analysis}

Data obtained were subjected to analysis of variance using statistical analysis software (SAS, 2004). Means \pm S.E.M were compared using Duncan's multiple range test (Duncan, 1955). Differences were considered to be statistically different at $\mathrm{P} \leq 0.05$

\section{Results and Discussion}

Table 2: Spermatological parameters of extended rabbit semen in $5 \%$ egg yolk plasma at $37^{\circ} \mathrm{C}, 0$ hour

\begin{tabular}{llllll}
\hline SPECIES & $\begin{array}{l}\text { MASS } \\
\text { MOTILITY (\%) }\end{array}$ & FPM (\%) & $\begin{array}{l}\text { LIVEABILITY } \\
(\%)\end{array}$ & $\begin{array}{l}\text { ACROSOME } \\
\text { INTEGRITY (\%) }\end{array}$ & $\begin{array}{l}\text { TOTAL } \\
\text { ABNORMALITY } \\
(\%)\end{array}$ \\
\hline CHICKEN & $61.00^{\mathrm{d}} \pm 1.00$ & $54.00^{\mathrm{c}} \pm 1.15$ & $84.66^{\mathrm{a}} \pm 1.45$ & $46.67^{\mathrm{c}} \pm 7.26$ & $15.00^{\mathrm{bc}} \pm 1.73$ \\
TURKEY & $72.33^{\mathrm{b}} \pm 1.76$ & $63.67^{\mathrm{b}} \pm 2.40$ & $80.33^{\mathrm{a}} \pm 7.96$ & $76.00^{\mathrm{a}} \pm 2.09$ & $11.67^{\mathrm{ab}} \pm 0.89$ \\
QUAIL & $65.33^{\mathrm{c}} \pm 0.33$ & $63.00^{\mathrm{b}} \pm 2.08$ & $84.67^{\mathrm{a}} \pm 2.67$ & $72.33^{\mathrm{ab}} \pm 1.45$ & $9.67^{\mathrm{a}} \pm 1.45$ \\
GUINEA FOWL & $81.00^{\mathrm{a}} \pm 6.65$ & $72.33^{\mathrm{a}} \pm 5.20$ & $77.00^{\mathrm{b}} \pm 1.53$ & $68.00^{\mathrm{b}} \pm 1.00$ & $18.33^{\mathrm{c}} \pm 4.64$ \\
MUSCOVY & $75.66^{\mathrm{ab}} \pm 5.67$ & $57.33^{\mathrm{bc}} \pm 3.71$ & $79.00^{\mathrm{ab}} \pm 6.66$ & $60.33^{\mathrm{bc}} \pm 6.07$ & $12.33^{\mathrm{b}} \pm 1.45$ \\
\hline
\end{tabular}

Means on the same column with different superscript are significantly different $(P \leq 0.05)$.

FPM- Forward Progressive Motility 
Popoola et. al. / Nig. J. Biotech. 32 (2017) 91 - 96

Table 3: Spermatological parameters of chilled rabbit semen in $5 \%$ egg yolk plasma extender at $5^{\circ} \mathrm{C}, 24$ hours

\begin{tabular}{llllll}
\hline SPECIES & $\begin{array}{l}\text { MASS } \\
\text { MOTILITY (\%) }\end{array}$ & FPM (\%) & $\begin{array}{l}\text { LIVEABILITY } \\
(\%)\end{array}$ & $\begin{array}{l}\text { ACROSOME } \\
\text { INTEGRITY (\%) }\end{array}$ & $\begin{array}{l}\text { TOTAL } \\
\text { ABNORMALITY } \\
(\%)\end{array}$ \\
\hline CHICKEN & $58.67^{\mathrm{b}} \pm 3.17$ & $47.00^{\mathrm{b}} \pm 2.51$ & $80.00^{\mathrm{a}} \pm 1.52$ & $61.67^{\mathrm{b}} \pm 2.33$ & $15.33^{\mathrm{b}} \pm 2.84$ \\
TURKEY & $62.67^{\mathrm{ab}} \pm 1.45$ & $50.33^{\mathrm{ab}} \pm 1.20$ & $72.67^{\mathrm{b}} \pm 6.35$ & $65.67^{\mathrm{a}} \pm 2.33$ & $13.33^{\mathrm{b}} \pm 2.40$ \\
QUAIL & $63.00^{\mathrm{ab}} \pm 2.51$ & $50.33^{\mathrm{ab}} \pm 1.85$ & $82.33^{\mathrm{a}} \pm 1.45$ & $66.00^{\mathrm{a}} \pm 3.05$ & $6.67^{\mathrm{a}} \pm 0.67$ \\
GUINEA FOWL & $66.33^{\mathrm{a}} \pm 3.29$ & $53.00^{\mathrm{a}} \pm 2.64$ & $62.33^{\mathrm{c}} \pm 1.45$ & $48.33^{\mathrm{d}} \pm 1.77$ & $24.33^{\mathrm{c}} \pm 2.84$ \\
MUSCOVY & $63.00^{\mathrm{ab}} \pm 4.17$ & $50.00^{\mathrm{ab}} \pm 3.05$ & $80.00^{\mathrm{a}} \pm 1.52$ & $57.33^{\mathrm{c}} \pm 0.88$ & $13.67^{\mathrm{b}} \pm 1.20$ \\
\hline
\end{tabular}

Means on the same column with different superscript are significantly different $(\mathrm{P} \leq 0.05)$.

FPM- Forward Progressive Motility.

Table 4: Spermatological parameters of chilled rabbit semen in $5 \%$ egg yolk plasma extender at $5^{\circ} \mathrm{C}, 48$ hours

\begin{tabular}{llllll}
\hline SPECIES & $\begin{array}{l}\text { MASS } \\
\text { MOTILITY (\%) }\end{array}$ & FPM (\%) & $\begin{array}{l}\text { LIVEABILITY } \\
(\%)\end{array}$ & $\begin{array}{l}\text { ACROSOME } \\
\text { INTEGRITY (\%) }\end{array}$ & $\begin{array}{l}\text { TOTAL } \\
\text { ABNORMALITY } \\
(\%)\end{array}$ \\
\hline CHICKEN & $50.00^{\mathrm{c}} \pm 2.88$ & $43.33^{\mathrm{c}} \pm 2.72$ & $73.33^{\mathrm{b}} \pm 4.26$ & $59.33^{\mathrm{c}} \pm 8.67$ & $16.00^{\mathrm{b}} \pm 3.05$ \\
TURKEY & $56.67^{\mathrm{c}} \pm 5.23 \mathrm{~b}$ & $46.00^{\mathrm{c}} \pm 5.03$ & $60.33^{\mathrm{c}} \pm 2.84$ & $44.67^{\mathrm{d}} \pm 2.60$ & $20.67^{\mathrm{bc}} \pm 0.67$ \\
QUAIL & $74.67^{\mathrm{a}} \pm 2.84$ & $62.33^{\mathrm{a}} \pm 2.18$ & $81.67^{\mathrm{a}} \pm 2.02$ & $78.00^{\mathrm{a}} \pm 4.35$ & $7.33^{\mathrm{a}} \pm 1.45$ \\
GUINEA FOWL & $64.33^{\mathrm{b}} \pm 2.90$ & $55.00^{\mathrm{b}} \pm 2.30$ & $66.00^{\mathrm{c}} \pm 3.78$ & $61.33^{\mathrm{bc}} \pm 0.89$ & $25.00^{\mathrm{c}} \pm 3.05$ \\
MUSCOVY & $65.33^{\mathrm{b}} \pm 3.52$ & $55.33^{\mathrm{b}} \pm 2.97$ & $76.67^{\mathrm{ab}} \pm 2.90$ & $64.00^{\mathrm{b}} \pm 1.52$ & $14.33^{\mathrm{b}} \pm 1.85$ \\
\hline
\end{tabular}

Means on the same column with different superscript are significantly different $(P \leq 0.05)$.

FPM- Forward Progressive Motility

The results showed that at $37^{\circ} \mathrm{C}$ before chilling storage, mass motility (\%) and forward progressive motility (FPM) in the diluted semen ranges from $81.00 \%$ to $61.00 \%$ and $72.33 \%$ to $54.00 \%$ representing the extended semen with guinea fowl yolk plasma and chicken yolk plasma respectively. Mass motility (\%) in guinea fowl egg yolk plasma (GEYP) extended rabbit semen was significantly different from that of the other samples compared except for Muscovy.

FPM in Quail (EYP) extended semen was similar to turkey. Liveability was similar among all the compared samples except in guinea fowl EYP extended rabbit semen $(77.00 \%)$ but guinea fowl was similar to only Muscovy $(79.00 \%)$. The best acrosome integrity was recorded in Turkey (EYP) extended rabbit semen $76.00 \%$ with significance difference when compared with chicken, guinea fowl and Muscovy. Turkey was similar to quail (EYP) extended semen in terms of acrosome integrity $(72.33 \%)$. The best combination of spermatological parameter required for fertility was found in quail egg yolk plasma (QEYP) containing extender having average mass motility of value $63.00 \%$, FPM of $50.33 \%$, liveability of $82.33 \%$, acrosome integrity of $66.00 \%$ and total abnormality of $6.67 \%$ being the least.

At 24 hours post chilling, mass motility and FPM of guinea fowl egg yolk plasma (GEYP) extended semen was significantly different from that of chicken however other were similar to both. Liveability of CEYP extended semen was significantly different from that of TEYP and GEYP $72.67 \%$ and $62.33 \%$ respectively. In terms of acrosome integrity, all samples were 
Popoola et. al. / Nig. J. Biotech. 32 (2017) 91 - 96

statistically different except TEYP and QEYP extended samples. The best total abnormality was recorded in QEYP extended semen $6.67 \%$ and it was significantly the highest total abnormality GEYP $24.33 \%$. All other samples were similar statistically in terms of total abnormality.

The superiority of some egg yolk sources (quail, chicken, turkey) has been attributed to the variable content of cholesterol, phospholipids and polyunsaturated fatty acids (Bathgate et al., 2006). In a cryopreservation experiment on Jackass semen, whole quail egg yolk was superior to whole chicken egg yolk in protecting sperm; attributed to its higher ratio of phosphatidylcholine and polyunsaturated fatty acids (Trimeche et. al., 1997, Burris \& Webb, 2006).

At 48 hours, QEYP extended semen gave the best result with the highest values of $74.67 \%, 62.33 \%, 81.67 \%$ and $78.00 \%$ for mass motility, FPM, liveability and acrosome integrity. The least liveability in TEYP samples was significantly different from the QEYP and CEYP but was similar to GEYP samples. GEYP samples were similar to CEYP and MEYP in terms acrosome integrity. Tremeche et. al. (1997) in a cryopreservation experiment using donkey semen found out that quail egg yolk was superior to chicken egg yolk in protecting sperm, which was attributed to its higher ratio of phosphatidylcholine and polyunsaturated fatty acids (PUFAs).

Courtens et. al. (1989) also reported that LDL was less aggressive to cells than egg yolk. They emphasized the possible adverse effect of calcium, present in high concentration in egg yolk. According to these authors, the acrosomes were modified or damaged, which could result from a rapid calcium influx into spermatozoa when the temperature is below $30^{\circ} \mathrm{C}$. These findings supported the selection of egg yolk plasma for the bio-fortification of rabbit semen extender as reported in this research work.

\section{Conclusion}

Bio-fortification of rabbit semen extender with 5\% Quail Egg Yolk Plasma enhances the spermatological parameters of rabbit semen desirable for fertility during artificial insemination. In comparison with other egg yolk plasma from other domesticated poultry species at 5\% inclusion level, QEYP gives the best result.

\section{References}

Bathgate, R., Maxwell W.M.C. and Evans G. (2006). Studies on the effect of supplementing boar semen cryopreservation media with different avian egg yolk types on in vitro postthaw sperm quality. Reprod. Domest. Ani. 41: 68-73.

Brun, J.M., Theau-Clement, M. andBolet, G. (2002).The relationship between rabbit semen characteristics and reproductive performance after artificial insemination.Ani. Reprod. Sci. 70: 139-149.

Burris, C., and Webb G.(2009). Effects of egg yolk source on the cryopreservation of stallion semen. J. Equi. Vet. Sci. 29: 336-7.

Cassinello, J., Abigar, T., Comendio, M. andRoldan E.R. (1998). Characteristics of the semen of three endangered species of gazelles (Gazella damamhorr, G. dorcasneglecta and G. cuvieri). J. Reprod. Ferti. 133:35-45.

Courtens J.L., Ekwall H., Paquignon M. and Ploen L. (1989). Preliminary study of water and some element contents in boar spermatozoa before, during and after freezing. J. Reprod. Fertil. 87: 613-26

Duncan, D.B. (1955). Multiple range and multiple $\mathrm{F}$ test. Biometrics, 11: 1-42.

El-Sherbieny, M.A., Kalaba, Z. M., El-Siefy, E.M.E. andAyat, R. A. (2012). Freezing and Fertilizing Capacity of Frozen Rabbit Semen Extended with Gelatin Addition. Asian J. Ani. Sci. 6: 291-295.

Hassan, H. E., Elamin K. M., Yousif I. A., Musa, A. M and El-khairey, M. A. (2012). Evaluation of Body Weight and some Morphometric Traits at Various Ages in Local Rabbits of Sudan. J. Ani. Sci. Adv. 2(4): 407415.

Nworgu, F.C. (2007). Economic importance and growth rate of broiler chicken served fluted pumpkin (Telfaria occidentalis). Afr. J. Biotech. 2:634-639. 
Pillet,E., Duchamp G.,Batellierc F.,Beaumald V., Antond M., Deshercese S., Schmitte E. and Magistrini M. (2011). Egg yolk plasma can replace egg yolk in stallion freezing extenders. Therio. 75:105-114.

Roca, J., Mart'ınez S.,Vázquez J.M., Lucas X., Parrilla I. andMart' ınez E.A. (2000). Viability and fertility of rabbit spermatozoa dilutedin Trisbuffer extenders and stored at $15^{\circ} \mathrm{C}$. Ani. Reprod. Sci. 64: 103-112.

SAS (2004). SAS/STAT User's Guide: Version 9.1.3. SAS Institute Inc., Cary, NC., USA. Ani. Sci., 6, 291-299.

Trimeche, A., Anton, M., Renard, P., Gandemer, G., andTainturier, D.(1997). Quail egg yolk A novel cryoprotectant for the freeze preservation of Poitou jackass sperm. Cryobiol. 34:385-93. 